\title{
A Survey of Alkyl Methacrylate Latexes as Aqueous Catalytic Media
}

\author{
Paul D. Miller and Warren T. Ford* \\ Department of Chemistry, Oklahoma State University, Stillwater, Oklahoma 74078
}

Received J uly 6, 1999. In Final Form: September 28, 1999

\begin{abstract}
Cationic polymer latexes serve as catalytic media for the hydrolysis of p-nitrophenyl esters by providing a morelipophilic environment into which these compounds can partition from the aqueous phase. Thelatex quaternary ammonium ions attract high local concentrations of reactive or catalytic ani ons into the waterswollen particles. We synthesized 32 different methacrylate and styrene latexes via a parallel synthetic route and tested their activities for the hydrolysis of p-nitrophenyl hexanoate. The most active latex is a copolymer of $75 \%$ 2-ethyl hexyl methacrylate and $25 \%$ vinyl benzyl chloride that was quaternized with tributylamine. The rate of hydrolysis at $30^{\circ} \mathrm{C}$ is 17 times faster using $0.6 \mathrm{mg} \mathrm{mL}^{-1}$ of latex in pH 9.4 borate buffer relative to control experiments that lacked polymer latex. Analysis of the kinetics shows that the latex activities depend primarily on the latex/water partition coefficients of p-nitrophenyl hexanoate. The latexes al so promotethe decarboxylati on of 6-nitrobenzisoxazole-3-carboxylate(6-NBI C) in aqueous media, and $0.6 \mathrm{mg} \mathrm{mL}^{-1}$ of thelatex from $75 \% 2$-ethyl hexyl methacrylateand $25 \%$ vinyl benzyl chloridequaternized with tributylaminegavean observed rate constant 10400 times that in water al one. Therateaccel erations of 6-NBIC decarboxylation are due to both favorable partitioning into the latex and faster intraparticle rate constants.
\end{abstract}

\section{Introduction}

Cationic polymers and colloids, such as polyelectroIytes, ${ }^{1-4}$ anion-exchange resins, ${ }^{5-7}$ surfactant micelles, ${ }^{1,2,8-10}$ and latexes, ${ }^{11-13}$ catalyze reactions of anions with uncharged organic compounds in aqueous media. The catalytic activities are due primarily to high local concentrations of the anionic and uncharged reactants in the small volume fraction of the polymer or colloid phase, or pseudophase, in the aqueous mixture, although enhanced intrinsic rate constants sometimes contribute.

Polystyrenelatexes containing quaternary ammonium ion exchange sites increase the rate of decarboxylation of 6-nitrobenzisoxazole-3-carboxylateup to 10000 times and therate of o-iodosobenzoate(IBA)-catalyzed hydrolysis of p-nitrophenyl diphenyl phosphate (PNPDPP) up to 6300 times faster than in aqueous solutions with no latex.12,13 The rate enhancements are as high or higher than those in cationic micelles, ${ }^{9}$ and the activity persists at very low particle concentrations, whereas surfactants have high catalytic activity only above the critical micelle concentration. In addition, the small $200 \mathrm{~nm}$ diameters of the latexes ensure that reaction rates are not limited by intraparticlediffusion, which often slows rates of reactions using ion-exchange resins and polymer-supported phase transfer catalysts.5,14

(1) Fife, W. K. Trends Polym. Sci. 1995, 3, 214.

(2) (a) Fendler, J. H.; Fendler, E. H. Catalysis in Micellar and Macromolecular Systems; Academic: New York, 1975. (b) Fendler, J . H. Membrane Mimetic Chemistry; Wiley: New York, 1982.

(3) Zheng, Y.; Knoesel, R.; Galin, J. Polymer 1987, 28, 2297.

(4) Yang, Y.; Engberts, J. J . Org. Chem. 1991, 56, 4300.

(5) Ford, W. T.; Tomoi, M. Adv. Polym. Sci. 1984, 55, 49.

(6) Tomoi, M.; Ford, W. T. Synthesis and Separations Using Functional Polymers; Sherrington, D. C., Hodge, P., Eds.; Wiley: Chichester, 1988; pp 181-207.

(7) Yamazaki, N. Polym. J . 1980, 12, 231.

(8) Bunton, C. A.; Savelli, G. Adv. Phys. Org. Chem. 1986, 22, 213. 681.

(9) Moss, R.; Alwis, K.; Bizzigotti, G. J . Am. Chem. Soc. 1983, 105,

(10) Moss, R.; Kotchevar, A.; Byeong, D. Langmuir 1996, 12, 2200.

(11) Lee, J. J.; Ford, W. T. J. Am. Chem. Soc. 1994, 116, 3753.

(12) Yu, H.; Ford, W. T. Langmuir 1993, 9, 1999.

(13) Lee, J.-J .; Ford, W. T. J . Org. Chem. 1993, 58, 4070.
One potentially important use of colloidal catalysts is hydrolysis of toxic organophosphates, phosphonates, and fluorophosphonates, which arewidely used as insecticides and arestockpiled as chemical warfareagents. ${ }^{15} \mathrm{Attempts}$ to catalyze the hydrolysis of diisopropyl fluorophosphate (DFP) in a polystyrene-based anion exchange latex at $\mathrm{pH}$ 11 gave no rate enhancement. ${ }^{16}$ One possible reason for lack of activity toward DFP is an unfavorable partition coefficient of the aliphatic DFP into the highly aromatic polystyrenelatex particles. Aliphaticlatex particles should absorb higher concentrations of al i phatic compounds and bemoreactive than the polystyreneparticles for reactions of aliphatic compounds. For this reason we synthesized a family of cationic latexes from copolymers of alkyl methacrylates and tested their activities for basic hydrolysis of p-nitrophenyl (PNP) esters and for decarboxylation of 6-nitrobenzisoxazole-3-carboxylate.

Wechose PNP esters as probes for a number of reasons. First, they are available in a wide range of carbon chain lengths which differ significantly in hydrophobicity. Second, it is easy to foll ow the appearance of $p$-nitrophenoxideion by UV-visiblespectrophotometry. And finally, extensive literature on the behavior of PNP esters allows for a more thorough understanding of the processes occurring in our systems. They have been used as model substrates for enzymemimics for many years, ${ }^{2,17}$ although their value is dubious because in many cases hydrolyses of esters having more basic leaving groups are not catalyzed. ${ }^{18}$ Themechanism of alkalinehydrolysis of PNP

(14) Tomoi, M.; Ford, W. T. J . Am. Chem. Soc. 1981, 103, 3821.

(15) Yang, Y.-C.; Baker, J . A.; Ward, J . R. Chem. Rev. 1992, 92, 1729.

(16) Walker, J .; Hoskins, F. US Army Natick Research Development and Engineering Center, personal communication.

(17) A few examples: (a) Blyth, C. A.; Knowles, J.J . Am. Chem. Soc. 1971, 93, 3017. (b) Blyth, C. A.; Knowles, J . R. J . Am. Chem. Soc. 1971, 93, 3021. (c) Hershfield, R.; Bender, M. L. J . Am. Chem. Soc. 1972, 94 , 1376. (d) Kunitake, T.; Okahata, Y.; Sakamoto, T. J . Am. Chem. Soc. 1976, 98, 7799. (e) Breslow, R.; Trainor, G.; Uleno, A.J . Am. Chem. Soc. 1983, 105, 2739. (f) Cram, D.J .; Lam, P. Y.; Ho, S. P.J . Am. Chem. Soc. 1986, 108, 839. (g) Broo, K. S.; Brive, L.; Ahlberg, P.; Baltzer, L. J . Am. Chem. Soc. 1997, 119, 11362 .

(18) Menger, F. M.; Ladika, M. J . Am. Chem. Soc. 1987, 109, 3145. 
acetate in aqueous solution is concerted according to an extension of Marcus theory, ${ }^{19}$ linear free energy relationships, ${ }^{20}$ isotope effects, ${ }^{21}$ and ab initio calculations. ${ }^{22}$

Hydrolyses of PNP alkanotates were among the first reactions discovered to be catalyzed by alkyltrimethylammonium ion micelles, ${ }^{23,24}$ and Menger and Portnoy introduced an enzyme-like model for the kinetics. ${ }^{24}$ I on exchange models were devel oped to analyze the kinetics in greater detail. ${ }^{8,25}$ We have applied a modified version of the pseudophase ion exchange model of micellar catalysis to the kinetics of hydrolysis of PNP esters in selected polymer latexes. ${ }^{26}$

Tostudy a variety of polymer latexes as catalytic media, we devised a diversity strategy for latex synthesis. ${ }^{27}$ Diversity strategies are employed at all major pharmaceutical companies for the synthesis of biologically active compounds, and have been used in search of superconducting, magnetic, and phosphorescent materials. ${ }^{28}$ They also have been used to synthesize potential catalysts, including polymer catalysts, for the production and testing of a large number of catalyst candidates in a short time. ${ }^{29}$ Since latex particles $<0.5 \mu \mathrm{m}$ in diameter are too small to be separated, we synthesized a series of alkyl methacrylate-based latex catalysts simultaneously in separate containers by a parallel approach.

\section{Experimental Section}

Materials. Vinylbenzyl chloride, butyl methacrylate, and 2-chloroethyl methacrylate(all from ScientificPolymer Products) and divinylbenzene (55-60\% active), isobutyl methacrylate, tetrahydrofurfuryl methacrylate, 2-ethylhexyl methacrylate, butoxyethoxyethyl methacrylate, and ethoxyethoxyethyl methacrylate (all from Aldrich) were distilled and filtered through a plug of alumina prior to use. A solubility test (dripping into hexane and examining for insoluble solid polymer) shortly before use indicated that no polymer was present. (m,p-Vinylbenzyl)trimethylammonium chloride was used as a $0.0482 \mathrm{M}$ aqueous solution (as determined with a chloride selective el ectrode). ${ }^{30}$ 2,2'-Azobis(N,N'-dimethyleneisobutyrami dine) di hydrochloride (VA044, Wako) was used as received after ${ }^{1} \mathrm{H}$ and ${ }^{13} \mathrm{C}$ NMR indicated no contamination. Trimethylamine (E astman, 25 wt $\%$ in methanol) and tributylamine (Eastman) were used as

(19) Guthrie, J . P. J . Am. Chem. Soc. 1991, 113, 3941.

(20) Stefanidis, D.; Cho, S.; Dhe-Paganon, S.; J encks, W. P. J . Am Chem. Soc. 1993, 115, 1650.

(21) (a) Hengge, A. C.; Hess, R. A. J . Am. Chem. Soc. 1994, 116, 11256. (b) Hess, R. A.; Hengge, A. C.; Cleland, W. W. J . Am. Chem. Soc. $1998,120,2703$

(22) Tantillo, D. J .; Houk, K. N. J . Org. Chem. 1999, 64, 3066.

(23) (a) Behme, M. T. A.; Fullington, J. G.; Noel, R.; Cordes, E. H. . Am. Chem. Soc. 1965, 87, 265. (b) Romsted, L. R.; Cordes, E. H. J Am. Chem. Soc. 1968, 90, 4404.

(24) Menger, F. M.; Portnoy, C. E. J . Am. Chem. Soc. 1967, 89, 4698. (25) (a) Berezin, I. V.; Martinek, K.; Yatsimirski, A. K. Russ. Chem Rev. Eng. Trans. 1973, 42, 787. (b) Quina, F. H.; Chaimovich, H. J. Phys. Chem. 1979, 83, 1844. (c) Quina, F. H.; Politi, M. J .; Cuccovia, I. M.; Baumgarten, E.; Martins-Frachetti, S. M.; Chaimovich, H. J. Phys. Chem. 1980, 84, 361. (d) Bunton, C. A. In TheChemistry of Enzyme Action; Page, M. I., Ed.; Elsevier: Amsterdam, 1984; pp 461-500. (e) Romsted, L. R. In Surfactants in Solution; Mittal, K. L., Lindman, B., Eds.; Plenum: New York, 1984; pp 1015-1068. (f) Bunton, C. A.; Nome, F.; Quina, F. H.; Romsted, L. S. Acc. Chem. Res. 1991, 24, 357.

(26) Miller, P. D.; Copeland, S. L.; Sanders, R.; Woodruff, A.; Gearhart, D.; Spivey, H. O.; Ford, W. T. Langmuir, in press.

(27) Miller, P. D.; Ford, W. T. Chem. Commun. 1998, 1151

(28) (a) Xiang, X.-D.; Sun, X.; Briceno, G.; Lou, Y.; Wang, K.-A.; Chang H.; Wallace-Freedman, W. G.; Chen, S.-W.; Schultz, P. G. Science1995, 268, 1738. (b) Briceno, G.; Chang, H.; Sun, X.; Schultz, P. G. Science 1995, 270, 273. (c) Sun, X.-D.; Gao, C.; Wang, J .; Xiang, X.-D. Appl. Phys. Lett. 1997, 70, 3353.

(29) (a) Menger, F. M.; Eliseev, A. V.; Migulin, V. A. J . Org. Chem 1995, 60, 6666. (b) Shimizu, K. D.; Cole, B. M.; Krueger, C. A.; Kuntz, K. W.; Snapper, M. L.; Hoveyda, A. Angew. Chem., Int. Ed. Engl. 1997, 36, 1704.

(30) Ford, W. T.; Yu, H.; Lee, J .J .; El-Hamshary, H. Langmuir 1993, 9, 1698. received. Triply deionized water having resistivity $>1 \times 10^{6} \Omega$ $\mathrm{cm}$ was used in all experiments. p-Nitrophenyl acetate (Pfaltz $\&$ Bauer) and all other p-nitrophenyl esters (Sigma) were used as $2.5 \mathrm{mM}$ solutions in acetonitrile (Aldrich). 6-Nitrobenzisoxazole-3-carboxylic acid was prepared as before. ${ }^{13}$

Parallel Polymerizations. The polymerizations werecarried out in sets of 12 and 7 test tubes, each containing a different monomer mixture. The test tubes were placed in a water bath at $60^{\circ} \mathrm{C}$, through holes in a sheet of polystyrene foam, which both immobilized the tubes and insulated the water bath. The polymerization mixtures werestirred using a six-platemagnetic stirrer (Lab-Line Instruments, Inc., model 1278) and a $7 \mathrm{~mm}$ stirbar in each tube. To each tube was added $3.5 \mathrm{~mL}$ of nitrogenpurged water. After $10 \mathrm{~min}$ at $60{ }^{\circ} \mathrm{C}, 1.0 \mathrm{~mL}$ of the $(\mathrm{m}, \mathrm{p}$ vinylbenzyl)trimethylammonium chloride solution (5 $\mathrm{mg}$ of monomer) was added. The mixture was stirred for $5 \mathrm{~min}$, and 5 $\mu \mathrm{L}$ of divinylbenzene, $175 \mu \mathrm{L}$ of vinylbenzyl chloride, and either $320 \mu \mathrm{L}$ of a single monomer or $160 \mu \mathrm{L}$ each of two monomers were added. The monomer mixture was stirred for $5 \mathrm{~min}$, and $5 \mathrm{mg}$ of VA044 in $0.5 \mathrm{~mL}$ of water was added. The tubes were covered with Durafilm to prevent evaporation of monomer and kept for $3.0 \mathrm{~h}$ at $60^{\circ} \mathrm{C}$. The latexes were filtered through a plug of cotton in a Pasteur pipet to remove any coagulum, which was always $<30 \mathrm{mg}$ ( $<8 \%$ of total polymer weight).

Quaternization of Latexes. A $4 \mathrm{~mL}$ aliquot of the latex was placed in a $10 \mathrm{~mL}$ screw cap vial, $2 \mathrm{~mL}$ of ethanol and $2 \mathrm{~mL}$ of 25 wt \% trimethylamine were added and the vial was capped tightly. Threesuch vials at a timewere placed in a stainless steel pressure reactor. A mixture of $12 \mathrm{~mL}$ of water, $6 \mathrm{~mL}$ of ethanol, and $6 \mathrm{~mL}$ of aqueous trimethylaminewas poured intothereactor outside the vials to balance the pressure. The reactor was seal ed and kept in a $60{ }^{\circ} \mathrm{C}$ oil bath for $48 \mathrm{~h}$

Purification of Latexes. About $2 \mathrm{~mL}$ of each latex sample was dialyzed for 2 days in $50000 \mathrm{MW}$ cutoff tubing against dei onized water. After dialysis the latex was drawn into a $5 \mathrm{~mL}$ syringe, thesyringewas fitted with a $0.1 \mu \mathrm{m} \mathrm{Milliporefilter,} \mathrm{and}$ the volume was reduced to about $0.75 \mathrm{~mL}$. The volume was brought back up to about $3 \mathrm{~mL}$ by adding water and was reduced toless than $1 \mathrm{~mL}$ repeatedly until the filtrate had a $\mathrm{pH}$ less than 7. Usually about $15-20 \mathrm{~mL}$ of water was needed. The typical solids content was $5-7 \mathrm{mg} / \mathrm{mL}$, determined by drying $1.00 \mathrm{~mL}$ samples to constant weight in a $130{ }^{\circ} \mathrm{C}$ oven. The percent conversion of vinylbenzyl chloride groups to quaternary ammonium groups was determined by potentiometrictitration with a chloride selective el ectrode. ${ }^{12}$

Kinetics. The latex samples were diluted to a solid content of $1.20 \mathrm{mg} / \mathrm{mL}$. A $2.00 \mathrm{~mL}$ aliquot of each latex was diluted to $40 \mathrm{~mL}$ with $0.02 \mathrm{M}$ borate buffer $(\mathrm{pH} 9.38)$ to give about $6.2 \times$ $10^{-5} \mathrm{M}$ of $\mathrm{N}^{+}$units. A $3.00 \mathrm{~mL}$ sample of thelatex/buffer solution was placed into a polystyrene cuvette. The solution was equilibrated at $30^{\circ} \mathrm{C}$ for $20 \mathrm{~min}, 5 \mu \mathrm{L}$ of $2.5 \mathrm{mM}$ PNP-hexanoate in acetonitrilewas added, and a UV - vis spectrum was taken every $0.9 \mathrm{~s}$. The average absorbance from 400 to $410 \mathrm{~nm}$ was plotted as a function of time, and $\mathrm{k}_{\mathrm{obs}}$ was calculated from data over the first $20 \%$ conversion using $\left.\ln \left[\left(A_{\text {inf }}-A_{o}\right) /\left(A_{\text {inf }}-A_{t}\right)\right]=k_{o b s} t\right)$. $A_{\text {inf }}$ was chosen by the experimenter. Correlation coefficients were $\geq 0.994$.

The procedurefor measuring rateconstants of decarboxylation of 6 -NBIC was reported before. ${ }^{13}$

\section{Results and Discussion}

Latexes. Thirty latex copolymers were prepared from monomer mixtures containing by weight $25 \%$ of vinylbenzyl chloride (70:30 m:p), $73 \%$ of various aliphatic methacrylates, and $1 \%$ of divinyl benzene $(0.55-0.60 \%$ of activeDVB) as a cross-linking agent. I n lieu of a surfactant, $1 \%$ of ( $m, p$-vinyl benzyl)trimethylammonium chloridewas used as a comonomer to stabilize the particles during growth. The latexes differed in the number and combination of aliphatic monomers present. Reaction of the vinylbenzyl chloride units with either trimethylamine (TMA) or tributylamine (TBA) produced anion exchange latexes having thestructurein Figure 1. Thelatex particles were 124-150 nm in diameter and contained 21-25 wt 


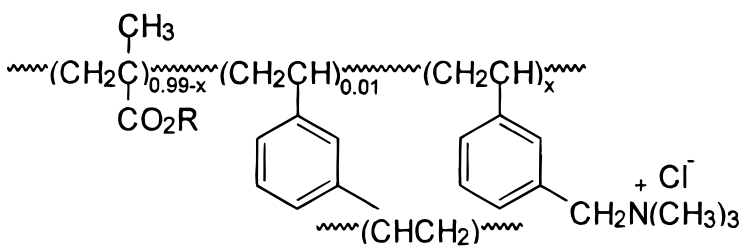

Figure 1. Structure of latex copolymers.

Table 1. Compositions of Quaternary Ammonium Ion Functionalized Latexes

\begin{tabular}{lcccc}
\hline composition & $\begin{array}{c}\text { quaternization } \\
\text { yield (\%) }\end{array}$ & $\mathrm{N}^{+} / \mathrm{g}^{\mathrm{a}}$ & $\mathrm{N}^{+} / \mathrm{mL}^{\mathrm{b}}$ & $\mathrm{N}^{+}$(mol \%) \\
\hline 2EHMA-TMA & 80.0 & 1.22 & 0.419 & 24.2 \\
2EHMA-TBA & 78.8 & 1.04 & 0.369 & 23.8 \\
BMA-TMA & 82.2 & 1.25 & 0.509 & 19.5 \\
BMA-TBA & 77.4 & 1.03 & 0.453 & 18.4 \\
S-TMA & 77.1 & 1.17 & 0.677 & 14.3 \\
S-TBA & 78.2 & 1.03 & 0.540 & 14.5
\end{tabular}

a mmol of $\mathrm{N}^{+}$per gram of dry latex. ${ }^{b} \mathrm{mmol}$ of $\mathrm{N}^{+}$per $\mathrm{mL}$ of swollen latex in $0.02 \mathrm{M} \mathrm{pH} 9.4$ borate buffer. ${ }^{c}$ M ole percent of $\mathrm{N}^{+}$ repeat units.

Table 2. Sizes of Quaternary Ammonium Ion Functionalized Latexes in Borate Buffer Solutions

\begin{tabular}{|c|c|c|c|c|c|c|c|c|}
\hline \multirow[b]{2}{*}{ composition } & \multirow{2}{*}{$\begin{array}{l}\mathrm{d}_{n^{\mathrm{a}}} \\
(\mathrm{nm})\end{array}$} & \multirow{2}{*}{$\begin{array}{l}\mathrm{d}_{\mathrm{w}}^{\mathrm{b}} \\
(\mathrm{nm})\end{array}$} & \multicolumn{3}{|c|}{$d_{h}(n m)^{c}$} & \multicolumn{3}{|c|}{ swelling ratio } \\
\hline & & & $\overline{0.002}$ & 0.01 & 0.02 & $\overline{0.002}$ & 0.01 & 0.02 \\
\hline & & & 21 & 203 & 198 & & & \\
\hline & & & & & & & & \\
\hline & & & 20 & & 19 & & & \\
\hline & & & 205 & 199 & 194 & 2 & 7 & \\
\hline & 128 & 12 & 171 & 164 & 160 & 2.4 & 2.1 & 1 \\
\hline -TBA & 124.0 & 124.8 & 168 & 162 & 169 & 2.5 & 2.2 & 2.1 \\
\hline
\end{tabular}

a Calculated using measurements of 50 particles from TEM negatives. Number averagediameter, $\mathrm{d}_{n}=\left(\sum \mathrm{N}_{\mathrm{i}} \mathrm{d}_{\mathrm{i}}{ }^{3} / \sum \mathrm{N}_{\mathrm{i}}\right) \mathrm{.}^{1 / 3}$ b Weight average diameter, $\mathrm{d}_{\mathrm{w}}=\left(\sum \mathrm{N}_{\mathrm{i}} \mathrm{d}_{\mathrm{i}}{ }^{6} / \sum \mathrm{N}_{i} \mathrm{~d}_{\mathrm{i}}{ }^{3}\right){ }^{1 / 3}{ }^{1 / 3}$ Hydrodynamic diameter from dynamic light scattering in various buffer strength solutions at $\mathrm{pH}$ 9.4. ${ }^{\mathrm{d}}\left(\mathrm{d}_{\mathrm{h}} / \mathrm{d}_{\mathrm{w}}\right)^{3}$ in buffer solutions of various strengths.

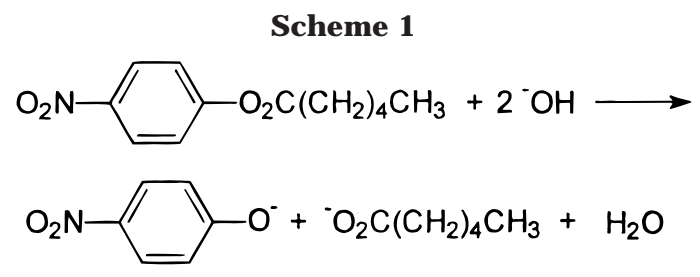

$\%$ (14-24 mol \%) of quaternary ammonium units. Properties of some representative latexes are presented in Tables 1 and 2 .

Influence of Latex Structure on Rates of PNP Alkanoate Hydrolysis. Totest catalytic activities of the particles, we measured the rates of basic hydrolysis of p-nitrophenyl (PNP) hexanoate (shown in Scheme 1) in $\mathrm{pH} 9.4$ borate buffer solutions with the quaternary ammonium sites in a greater than 10 -fold excess over substrate. PNP hexanoate is hydrophobic but still completely soluble at the concentration needed for kinetic measurements. All experiments had half-lives in therange of $130-930 \mathrm{~s}$. The ratios of rate constants in latex dispersions to rate constants in buffer al onearein Tables 3 and 4 .

Table3 shows that the 2-ethylhexyl methacrylatelatex (8) has the highest catalytic activity of all of the TMA quaternized latexes. All of the methacrylate latexes have higher activity than the styrene-based TMA latex (29). Latexes 15-28 contain combinations of monomers, and those containing 2-ethylhexyl methacrylate (latexes 16, 19, and 23) are the most active.
Table 3. Relative Rate Constants of Hydrolysis of PNP-Hexanoate in Latexes Quaternized with Trimethylamine

\begin{tabular}{clr}
\hline latex & \multicolumn{1}{c}{ methacrylate } & \\
\hline $\mathbf{1}$ & n-butyl & $\mathrm{k}_{\mathrm{obs}} / \mathrm{k}_{\mathrm{w}}$ \\
$\mathbf{2}$ & n-hexyl & 6.1 \\
$\mathbf{3}$ & n-octyl & 6.5 \\
$\mathbf{4}$ & n-decyl & 9.5 \\
$\mathbf{5}$ & n-dodecyl & 10.2 \\
$\mathbf{6}$ & isobutyl & 10.7 \\
$\mathbf{7}$ & 2-ethylbutyl & 6.5 \\
$\mathbf{8}$ & 2-ethylhexyl & 6.1 \\
$\mathbf{9}$ & 2-chloroethyl & 12.5 \\
$\mathbf{1 0}$ & butoxyethoxyethyl & 5.6 \\
$\mathbf{1 1}$ & ethoxyethoxyethyl & 5.8 \\
$\mathbf{1 2}$ & tetrahydrofurfuryl & 5.5 \\
$\mathbf{1 3}$ & tetrahydropyranyl & 7.1 \\
$\mathbf{1 4}$ & furfuryl & 5.6 \\
$\mathbf{1 5}$ & n-hexyl/2-ethylbutyl & 5.8 \\
$\mathbf{1 6}$ & n-octyl/2-ethylhexyl & 6.5 \\
$\mathbf{1 7}$ & butyl/butoxyethoxyethyl] & 10.7 \\
$\mathbf{1 8}$ & isobutyl/ethoxyethoxyethyl & 6.5 \\
$\mathbf{1 9}$ & 2-ethylhexyl/butoxyethoxyethyl & 6.2 \\
$\mathbf{2 0}$ & 2-chloroethyl/ethoxyethoxyethyl & 10.5 \\
$\mathbf{2 1}$ & 2-chloroethyl/butyl & 5.6 \\
$\mathbf{2 2}$ & 2-chloroethyl/tetrahydrofurfuryl & 6.2 \\
$\mathbf{2 3}$ & 2-chloroethyl/2-ethylhexyl & 6.5 \\
$\mathbf{2 4}$ & tetrahydrofurfuryl/ethoxyethoxyethyl & 9.9 \\
$\mathbf{2 5}$ & tetrahydrofurfuryl/butyl & 6.6 \\
$\mathbf{2 6}$ & tetraydrofurfuryl/butoxyethoxyethyl & 6.4 \\
$\mathbf{2 7}$ & tetrahydrofurfuryl/isobutyl & 7.0 \\
$\mathbf{2 8}$ & tetrahydrofurfuryl/2-ethylhexyl & 7.1 \\
$\mathbf{2 9}$ & styrene & 11.2 \\
& 2 & 2.3
\end{tabular}

a $0.6 \mathrm{mg} / \mathrm{mL}$ of latex with $\left[\mathrm{N}^{+}\right]=62 \mu \mathrm{M}$ and $4.2 \mu \mathrm{M}$ PNP hexanoate in $0.02 \mathrm{M}$ borate buffer at $\mathrm{pH} 9.4$ and $30.0^{\circ} \mathrm{C}$. Data are averages of two to three experiments that deviated over a range of $\leq 5 \%$ of the reported $\mathrm{k}_{\mathrm{obs}} . \mathrm{k}_{\mathrm{w}}=3.26 \times 10^{-4} \mathrm{~s}^{-1}$.

Table 4. Relative Rate Constants of Hydrolysis of PNP Hexanoate in Latexes Quaternized with Tributylamine

\begin{tabular}{clc}
\hline latex & \multicolumn{1}{c}{ composition $^{\mathrm{a}}$} & $\mathrm{k}_{\mathrm{obs}} / \mathrm{k}_{\mathrm{w}}{ }^{\mathrm{b}}$ \\
\hline $\mathbf{3 0}$ & 2-ethylhexyl methacrylate & 16.5 \\
$\mathbf{3 1}$ & n-butyl methacrylate & 15.7 \\
$\mathbf{3 2}$ & styrene & 12.0
\end{tabular}

a See footnotes of Table 1. b See footnotes of Table 3.

Longer-chained and branched aliphatic methacrylate latexes (2-8) were also investigated. Activity increased with alkyl methacrylate chain length from n-hexyl to n-dodecyl methacrylate, and the magnitude of thechange decreased with each two additional carbon atoms. The 2-ethylhexyl methacrylate latex (8) is more active than then-octyl methacrylate (3), and then-octyl/2-ethylhexyl methacrylate (16) has intermediate activity.

Table 4 indicates that particles containing tributylammonium ions are more active than those containing trimethylammonium ions. The difference between the activity of TBA and TMA latexes is much morepronounced for polystyrene than for polymethacrylates.

To determine what factors are responsible for the differences in activities between latexes, we analyzed details of the kinetics of hydrolysis of p-nitrophenyl acetate, hexanoate, and octanoate using thestyrene, butyl methacrylate, and 2-ethylhexyl methacrylate latexes quaternized by TMA and TBA. The data were analyzed by eqs 1 and 2, which come from Scheme 2, where

$$
\begin{gathered}
k_{o b s}[S]_{t}=k_{w}[S]_{w}+k_{L}[S]_{L} \\
k_{o b s}=\left(k_{w} / K+k_{L}\left[N^{+}\right]\right) /\left(1 / K+\left[N^{+}\right]\right)
\end{gathered}
$$

$\mathrm{k}_{\mathrm{obs}}$ is the observed rate constant, $\mathrm{k}_{\mathrm{w}}$ is the rate constant 


\section{Scheme 2}

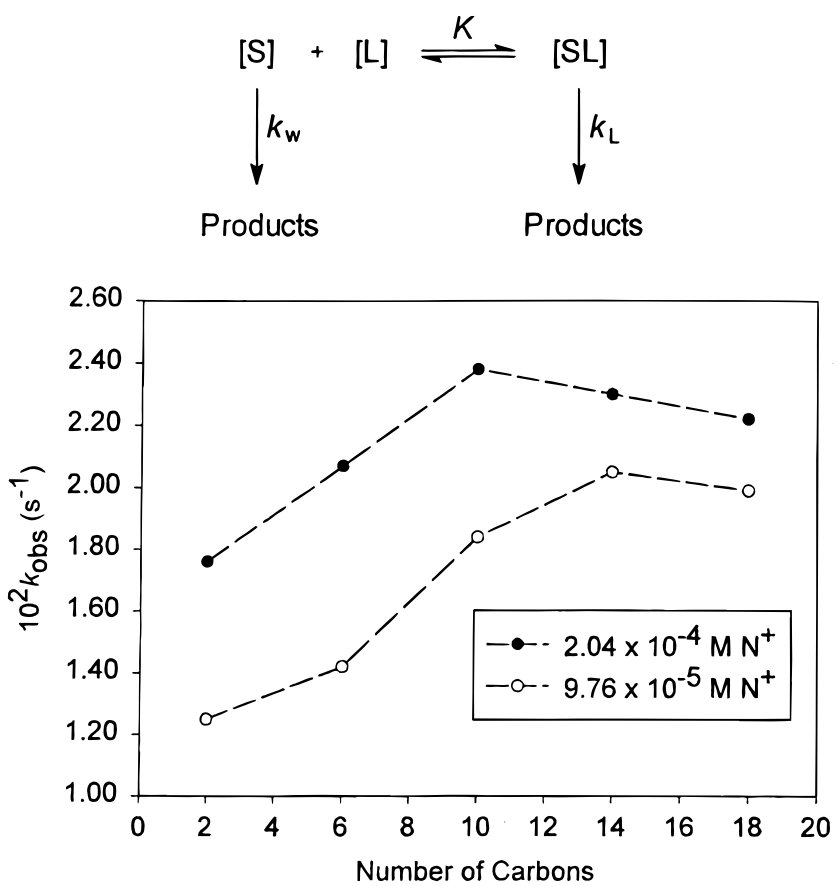

Figure 2. Dependence of observed rate constant of hydrolysis of p-nitrophenyl esters at $30^{\circ} \mathrm{C}$ on the alkanoate chain length. Thecatalyst was a poly(2-ethylhexyl methacrylate) quaternized with tributylamine in pH 9.4 borate buffer.

in the absence of particles, $k_{L}$ is the intraparticle pseudofirst-or der rate constant, and $\mathrm{K}$ is a distribution constant of substrate between the aqueous phase and the particle phase. ( $\mathrm{K}$ is the binding constant of the Menger-Portnoy model). ${ }^{24}$ Nonlinear regression analysis of rate constants at varied particle concentrations gave values of $\mathrm{k}_{\mathrm{L}}$ and $K .{ }^{31}$ The details of the data analysis are reported elsewhere. ${ }^{26}$

The intraparticle rate constants for hydrolysis of the threePNP estersarevery similar for each of thesix latexes. The major differences in thelatex activities are dueto the distribution constants: the longer the aliphatic chain of the PNP ester, the greater its affinity for the latex, and the longer the al iphatic chain of the methacrylate latex, the higher the value of $\mathrm{K}$. Thus a more aliphatic latex extracts a larger fraction of substrate from the aqueous phase. The TBA latexes extract more of the substrates than the TMA latexes, and the difference in values of intraparticle rate constants $k_{\mathrm{L}}$ for TBA and TMA latexes is much larger for polystyrene than for poly(butyl methacrylate) or poly(2-ethylhexyl methacrylate). The methacrylates already have aliphatic character, so the TBA effect is not as great.

The model of Scheme 2 does not account for ion selectivities. We have performed a more detailed kinetic analysis of hydrolyses of PNP acetate, hexanoate, and octanoate using the six latexes reported in Table 2 by an ion exchange model. ${ }^{26}$ The results of the analysis were that the intraparticle second-order rate constants for reaction of hydroxide with PNP esters were almost the same for all latexes, so that differences in partition coefficients of the substrates between the particle and water phases were completely responsible for the differences in observed rate constants. The overall rate accelerations also were promoted by approximatedly 10fold higher concentration of hydroxideion in the particles than in the external buffer solution.

(31) Tee, O. S.; Federtchenko, A. A. Can. J . Chem. 1997, 75, 1434.

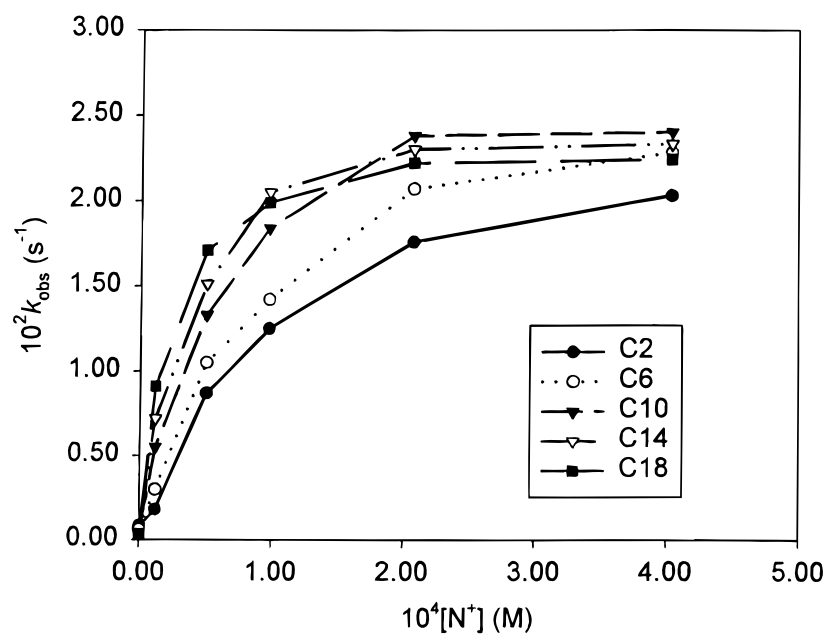

Figure 3. Dependence of observed rate constant on the concentration of poly(2-ethyl hexyl methacrylate)-TBA in $\mathrm{pH}$ 9.4 borate buffer at $30.0^{\circ} \mathrm{C}$.

Table 5. Intraparticle Rate Constants and Distribution Constants for Hydrolysis of Long Chain PNP Alkanoates

\begin{tabular}{ccc}
\hline PNP ester & $10^{3} \mathrm{~K}_{\mathrm{L}}, \mathrm{s}^{-1}$ & $10^{-4} \mathrm{~K}, \mathrm{M}^{-1}$ \\
\hline decanoate & 4.8 & 9.0 \\
tetradecanoate & 4.5 & 9.1 \\
octadecanoate & 4.4 & 9.3
\end{tabular}

a $\mathrm{K}_{\mathrm{L}}$ and $\mathrm{K}$ are defined in Scheme 2.

Dependence of Rate of Hydrolysis on PNP Alkanoate Chain Length. We also measured the activity of the latexes for hydrolysis of PNP esters with chain lengths up to $C_{18}$. Figure 2 shows that as the chain length increases, $\mathrm{k}_{\mathrm{obs}}$ increases toa maximumand then decreases. The chain length at which this maximum $k_{o b s}$ is reached decreases as the concentration of the polymer increases. Such dependence of rates of hydrolysis on chain length of PNP alkanoates also has been observed with soluble 4-dialkylaminopyridine-containing polysiloxanes as catalysts in 50/50 methanol/water. ${ }^{32}$ The observed rate constant is the sum of the rate constant inside the particles and the rate constant in the aqueous phase (eq 1). The rate inside the particles is a function of the fraction of substrate in the particles and the intraparticle rate constant. The longer the alkanoate chain, the larger is the value of $K$ and, therefore, the higher the fraction of substrate in the particles at a given polymer concentration. ${ }^{26}$ When the polymer concentration is high enough that essentially all of a given PNP ester is in the particle phase, the relative rates of hydrolysis of all esters with longer alkanoatechain lengths depend only on therelative intraparticle rate constants, which decrease with increasing chain length because chain coiling slows attack of hydroxide ion at the ester group. ${ }^{31,33}$

Rate constants for the hydrolysis of various PNP alkanoates up to $C_{18}$ at varied concentration of the 2-E HMA-TBA latex are shown in Figure 3. The observed rate constants increase with increasing particle concentration until essentiallyall of thesubstrateis in the particle phase and then level off. The maximum rate constant occurs at lower particle concentration as the alkanoate chain length increases. Analysis of the data in Figure 3 using eqs 1 and 2 leads to the calculated intraparticle pseudo-first-order rate constants and distribution con-

(32) Wang, G.-J .; Fife, W. K. J . Am. Chem. Soc. 1998, 120, 883.

(33) Murakami, Y.; Aoyama, Y.; Kida, M.J .Chem. Soc., Perkin Trans. 2 1977, 1947. 
Scheme 3<smiles>N#Cc1ccc([N+](=O)[O-])cc1[O-]</smiles>

Table 6. Relative Rate Constants of Decarboxylation of 6-Nitrobenzisoxazole-3-carboxylate in Polymer Latexes

\begin{tabular}{lrlr}
\hline \multicolumn{1}{c}{ composition $^{\mathrm{a}, \mathrm{b}}$} & $\mathrm{k}_{\mathrm{obs}} / \mathrm{k}_{\mathrm{w}}{ }^{\mathrm{c}}$ & \multicolumn{1}{c}{ compositiona,b } & $\mathrm{k}_{\mathrm{obs}} / \mathrm{k}_{\mathrm{w}}{ }^{\mathrm{c}}$ \\
\hline 2-ethylhexyl (TBA) & 10400 & isobutyl & 3300 \\
styrene (TBA) & 9600 & tetrahydrofurfuryl & 3200 \\
2-ethylhexyl & 8300 & n-butyl & 2900 \\
n-octyl/2-ethylhexyl & 7400 & styrene & 900 \\
n-butyl (TBA) & 6000 & butoxyethoxyethyl & 400 \\
n-decyl & 4400 & ethoxyethoxyethyl & 200 \\
n-octyl & 4100 & &
\end{tabular}

a All latexes werequaternized with trimethylamineexcept those designated TBA. ${ }^{\mathrm{b}} 0.6 \mathrm{mg} / \mathrm{mL}$ of latex with $\left[\mathrm{N}^{+}\right]=62 \mu \mathrm{M}$ and 1.00 $\times 10^{-5} \mathrm{M}$ substratein $2 \mathrm{mM} \mathrm{NaOH}$ at $30.0^{\circ} \mathrm{C}$. Reaction was followed by the appearance of 2-cyano-5-nitrophenoxide at $426 \mathrm{~nm} .{ }^{\mathrm{C}} \mathrm{k}_{\mathrm{w}}=$ $3.4 \times 10^{-6} \mathrm{~s}^{-1}$.

stants listed in Table 5. The intraparticle rate constants decrease slightly with increasing chain length, and the distribution constants are all the same within experimental error.

Decarboxylation of 6-Nitrobenzisoxazole-3-carboxylate. Some of the latexes were tested for the ability to promote the unimolecular decarboxylation of 6-nitrobenzisoxazole-3-carboxylate (Scheme 3). The latex quaternaryammoniumion concentration was greater than 10-fol d excess over the substrate concentration (Scheme 2). The reaction followed first-order kinetics for $>3$ halflives, but only data from the first $20 \%$ conversion were anal yzed. Theratios of rateconstants in latex dispersions vs water alone are presented in Table 6. Again the
Table 7. Intraparticle Rate Constants and Distribution Constants for the Decarboxylation of 6-Nitrobenzisoxazole-3-Carboxylate in Latexes at $30.0^{\circ} \mathrm{C}$

\begin{tabular}{clrrr}
\hline & & \multicolumn{1}{c}{$10^{3} \mathrm{k}_{\mathrm{L}}$} & & $\mathrm{K}, \mathrm{M}^{-1}$ \\
latex & \multicolumn{1}{c}{ composition } & $\mathrm{S}^{-1}$ & $\mathrm{k}_{\mathrm{L}} / \mathrm{k}_{\mathrm{w}}$ & \\
\hline $\mathbf{1}$ & 2-ethylhexyl methacrylate (TBA) & 44 & 13000 & 4200 \\
$\mathbf{2}$ & styrene (TBA) & 58 & 17000 & 2930 \\
$\mathbf{3}$ & 2-ethylhexyl methacrylate (TMA) & 39 & 11000 & 3600 \\
$\mathbf{1 1}$ & styrene (TMA) & 15 & 4000 & 980
\end{tabular}

2-ethylhexyl methacrylate latexes were most active, and the tributylamine quaternized latexes were more active than their trimethylamine quaternized analogues.

The rate constants at varied particle concentrations were analyzed by eqs 1 and 2 . Table 7 shows a comparison of the intraparticle rate constants and the distribution constantsfor the decarboxylation promoted by polystyrene and poly(2-ethylhexyl methacrylate) copolymer latexes quaternized with tributylamine. Even though the $\mathrm{K}_{\mathrm{L}}$ for the polystyrene-TBA latex is larger than that for the methacrylate latex, $\mathrm{K}$ is much smaller, resulting in an observed ratethat is lower than that for the methacrylate latex (Table 6). Comparing the polystyrene-TBA latex with the polystyrene-TMA latex, the decarboxylation in the TBA latex is 10.7 times faster (Table 6 ) as a result of both higher $\mathrm{K}_{\mathrm{L}}$ and $\mathrm{K}$ values by factors of 3.8 and 3.0, respectively. Thus the intraparticle rate constants are more important contributors to the overall rates of the decarboxylation than to the rates of PNP alkanoate hydrolyses, where the intraparticle first-order rate constants depended very little on the polymer composition. ${ }^{26}$

Acknowledgment. Wethank theU.S. Army Research Office for financial support and the Phillips Petroleum Co. for a research fellowship (P.D.M.).

LA9908790 